Chapter 9

\title{
The Global Compact and Its Critics: Activism, Power \\ Relations, and Corporate Social Responsibility
}

Graham Knight and Jackie Smith

PUBLISHED IN: 2008 Graham Knight and Jackie Smith, "The Global Compact and Its Critics: Activism, Power Relations, and Corporate Social Responsibility” Pp. 191-214 in Discipline and Punishment in Global Politics. Janie Leatherman, Ed. Palgrave Macmillan.

\section{The Global Compact and Corporate Social Responsibility: A Field of Contention}

On June 23, 2004 a network of non-governmental organizations (NGOs) and other civil society actors, many of them associated with the Alliance for a Corporate-Free United Nations (ACFUN), held a public symposium to discuss the relationship between the United Nations (UN) and the issue of corporate accountability. The occasion for the event was another, quite different gathering, the Global Compact Leaders Summit being held the same day at UN headquarters. The Global Compact Counter-Summit, as the symposium was billed, was devoted primarily to voicing concern and criticism that the UN particularly through its Global Compact project, was becoming too closely tied to corporate interests and compromising its neutrality and integrity as an instrument of global governance. The following month representatives from ACFUN and other groups participating in the Counter-Summit issued a Joint Civil Society Statement on the Global Compact and Corporate Accountability calling for effective measures to enforce corporate accountability in areas such as human rights and the environment. (Joint Civil Society Statement, 2004)

As social movement researchers have noted, the growth of corporate power that has accompanied neo-liberal globalization has resulted in the development of a transnational social justice movement challenging corporate and government conduct around issues such as 
inequalities, rights, social exclusion, and the environment (della Porta et al. 2006). The participants in the Counter-Summit were part of this broad network of activism aimed at calling corporate power to account, questioning the capitulation of governments to the interests of global capital, and contesting the ideological monologue of market supremacy. Less often recognized by observers of social activism, however, is the growth of a kind of corporate counter movement that recognizes the social as well as economic impact of corporate behaviour and the need to promote social responsibility on the part of corporations. While corporate social responsibility (CSR) has a long history, dating back to earlier forms of business philanthropy, it has recently taken a new lease on life as an attempt to respond to the concerns of neo-liberalism's critics about the disruptive impact of market forces on civil society and social well-being. The Global Compact represents what is to date the most ambitious attempt to institutionalize CSR as a dimension of global governance.

The Global Compact (GC) was first mooted by U.N. Secretary General Kofi Annan at the 1999 World Economic Forum. The GC itself was inaugurated the following year as a multilateral scheme involving participation from individual businesses, business associations, civil society organizations such as NGOs and labour union federations, and UN agencies. The centrepiece of the initiative was a code that comprised nine principles to which the Compact's participants were asked to commit themselves. The nine principles pertained to three areas of concern--human rights, labour rights, and environmental protection--and were drawn from three existing documents, the Universal Declaration of Human Rights, the International Labour Organization's Fundamental Principles on Rights at Work, and the Rio Earth Summit (United Nations Environmental Programme 2002). A tenth principle relating to financial probity and anticorruption was subsequently added to the code (Greenleaf Publishing 2004; United Nations 
Global Compact 2006). The rationale of the code was to establish commitment to and consensus around universal principles at a global as opposed to national or regional level.

The GC was designed primarily as an instrument of socialization, a means to humanize and moralize the cold calculus of market rationality and its principal agents, transnational corporations (TNCs) (Williams 2004); hence it was closely associated with another, contemporaneous U.N. initiative, the Millennium Development Goals. The GC is an instrument of socialization in the double sense. It is designed to encourage social learning based on the best practices model of corporate performance, and to incorporate its participants into networks of interdependency and co-operation realized chiefly through communicative action. As is true of CSR generally, dialogue plays a central role in how the GC represents itself to the world. The Compact set out to achieve its goals in three ways. The first is the establishment of learning networks in which participating corporations report on their progress in promoting the ten principles. The second is through policy discussions among participants about appropriate corporate responses to problematic situations, such as operating in conflict zones. Both of these seem in practice to centre on helping corporations learn better avoidance behaviour, ie. on reducing the risk of being complicitous in rights abuses, environmental harm, or corruption. The third consists of public/private partnership projects aimed at tackling particular problems in developing countries, the most prominent to date being programmes to enhance awareness and prevention of HIV/AIDS. It is this latter mechanism that is the most oriented to concrete action where rights and security are imperilled.

In the spectrum of CSR initiatives the GC is best characterized as a promotional endeavour. It relies on voluntary compliance and self-policing on the part of its corporate participants, and does not entail any mechanisms of external monitoring, verification or 
sanctioning to ensure the latter are actually living up to their commitments and claims. The GC typifies the attempt to develop alternative mechanisms of corporate governance to fill the gap created by the roll-back of state-centred forms of regulation in the face of neo-liberal hegemony, the growth of corporate power, and the emergence of new issues and problems resulting from globalization (Paine 2000). The initiative is a largely top-down attempt to generate a hybrid, voluntary system of engaging TNCs in socially and environmentally responsible practices in what has been termed the "new global public domain" by John Gerard Ruggie (2004), an academic who is the recently appointed U.N. special envoy on business and human rights and a former special advisor on the GC.

Since its inception, however, the GC has been subject to wide-ranging criticism. These criticisms fall into three related areas. The first is ideology. Many activists see the GC as another step in the direction of the U.N. becoming closer to the interests of TNCs, a process that began in earnest in the early 1990s with the closure of the U.N.'s Centre on Transnational Corporations. ACFUN and other activist organizations see the GC as compromising the political and ideological neutrality of the U.N. while providing an opportunity for participating TNCs to exploit the U.N.'s prestige for symbolic capital and public relations gains. Drawing on the communicational repertoire of the environmental movement, ACFUN and other critics have charged TNCs affiliated with the GC with "blue-washing," wrapping themselves in the U.N. flag as a way to enhance their public image as ethically responsible (Transnational Resource and Action Center 2000; CorpWatch 2002). Rather than representing an unconditional capitulation to an untrammelled ideology of corporate neo-liberalism, however, others see the GC as redolent of 'third way' politics that have attempted to give neo-liberalism a more social democratic face (Hughes and Wilkinson 2001). 
The second area of criticism concerns the institutional implications of the GC. Observers from different political perspectives acknowledge that globalization has been accompanied by the expansion of corporate rights and power by making nation state boundaries more permeable to economic transactions of all kinds (cf. Hughes and Wilkinson 2001; Paine 2000). This process is best symbolized by the growing importance of the World Trade Organization (WTO) and its ability to impose legally enforceable constraints on national governments. There have, however, been no comparable institutional developments with respect to corporate obligations and responsibilities. As an attempt to address these obligations and responsibilities, the GC in no way matches the authority and capacity of the WTO. Equally importantly, the formation of the GC represents an institutional separation of rights and responsibilities on terms that are not only uneven but also free the WTO from the need to concern itself seriously with the social, environmental, and ethical side-effects of neo-liberal economics. While this institutional separation may diminish to some extent the WTO's legitimacy, it nonetheless simplifies its remit in terms of business as usual. The GC becomes the premier global forum in which these issues are taken up, but chiefly in the form of communicative rather than material action.

The third area of criticism concerns the specifics of the GC's aims, structure and procedures. The focus of criticism here has been largely what is missing, what the GC does not and cannot do, but should nonetheless be done. The core criticism here is that the GC is just yet another scheme that relies on voluntary participation and self-policing by TNCs. It lacks any legally binding, enforceable mechanisms to ensure TNCs are accountable for their actions and inactions. From the criticism of voluntarism flows a host of other reservations: viz. the GC lacks a system to monitor corporate behaviour, to ensure participating TNCs report on their conduct in an objectively measurable, transparent, and verifiable way, and to ensure that problems are 
rectified successfully (Martens 2004; Simons 2004) . Putting the accent on promoting corporate responsibility through socialization and communicative action means that the GC fails to achieve corporate accountability in a legally effective way (Williams 2004). The ideological and institutional critiques of the GC converge with these organizational and procedural criticisms. The GC and CSR generally do not address the root problem of how the balance of cultural, political and economic power has been shifting in a direction that undermines democratic governance, nor do they offer a feasible instrument to promote social and economic development that is not compromised by the imperatives of competitiveness and profitability (inter alia Blowfield, 2005; Blowfield \& Frynas, 2005; Frynas, 2005; Jenkins, 2005; Newell, 2005; Shamir, 2004).

These criticisms have come from a variety of sources including academics and even observers within the U.N. system itself (Bendell 2004; Utting 2002). The most comprehensive and sustained criticism, however, has come from social activists who see voluntary CSR schemes as simply a means to reproduce and legitimate existing power relations rather than bring about social and economic development of a more equitable and sustainable kind. ACFUN was the most vocal critic in the GC in the early 2000s. It is a network centred on the U.S.-based corporate watchdog CorpWatch, and draws its affiliates from among Northern and Southern NGOs and activist organizations including the Brazilian Institute for Social and Economic Analysis, Corporate Europe Observatory, the Thailand based Focus on the Global South, and the International NGO Committee on Human Rights in Trade and Investment based in India. Concerns about effectiveness, however, have also been expressed from within the GC. After the 2004 Leaders Summit, for example, NGO members of the Compact such as Amnesty International issued a public statement criticizing the initiative for falling "far short of 
expectations" and calling for stronger measures to ensure corporate accountability (Amnesty International 2004). It is striking that the criticisms and recommendations from NGOs within the GC do not differ markedly from those being made by outside groups such as ACFUN.

The relationship between the GC and its civil society critics reflects general changes in the forms of contention and repertoires of action that have characterized the development of the global social justice movement. This movement is something of a hybrid of 'old' and 'new' social movements. Like the former, particularly the labour movement, it is concerned with issues of material inequality, security and social well-being; like 'new' social movements it is also oriented to issues of identity, cultural rights and autonomy. It has a reticular structure, comprising a fluid network, or network of networks, whose nodes are different groups, organizations and associations that come together out of shared interest in particular issues in a contingent and often temporary way (della Porta et al. 2006). This network structure has been facilitated by the development of new digital technologies, notably the Internet. These allow for low cost, instantaneous communication that enhances mobilization capabilities and greater flexibility and responsiveness in decision-making and campaigning. As Bennett (2003) has argued, communication has become the organizational logic of networked forms of social activism.

The importance of communication also extends to movement strategy and tactics. Social movements have long had an interdependent if somewhat tenuous relationship with the mainstream media (Smith et al. 2001). To some extent, however, this relationship has changed as the spread of digital media has decentralized and pluralized opportunities for alternative forms of communication. The implications are twofold. On the one hand, movements such as the social justice movement tend to function in terms of a strategy of permanent campaigning (Bennett, 
2003). On the other hand, the targets of activism are varied and constantly shifting in response to new information, developments and events. As a result, the role of communication is accentuated as the logic that ties together different tactics at the same time that it also expands the movement's tactical repertoire. An increasingly important dimension of activism, and one that is especially pronounced in the case of CSR initiatives like the GC, is the constant surveillance and monitoring of major institutions like corporations, governments and other governance bodies, and the accumulation, analysis and publication of information about their actions and inactions in the form of reports, newsletters, and other forms of public discourse (for example see inter alia Amnesty International 2005). Social justice activism has taken on an investigative, almost forensic, quality. Contention between social movements and their institutional targets increasingly involves the presentation and rebuttal of evidence, and gatherings such as the Counter Summit are a way in which activists not only parody the practices of their targets but also make evidence-based claims making publicly available for deliberation and debate.

\section{Contention and Power Relations}

The enhanced role that communication plays in transnational social movements also speaks to shifting configurations of power relations. Social movement research has generally seen changes in the forms, frequency and intensity of contention in terms of the distribution of power and how this in turn shapes the distribution of other resources, opportunities, threats and grievances. While not discounting the importance of power inequalities, it is important to recognise that the forms, frequency and intensity of contention are also shaped by different modes or techniques of power, by different ways in which power can be exercised and resisted. The repertoire of activities that social movement networks undertake, from lobbying to protest to 
humanitarian assistance to surveillance, monitoring and the dissemination of information is implicated in the exercise of power and the circulation of power effects. As Foucault has argued, modern forms of power in particular consist of more than simply practices of constraint and deprivation. Power is productive inasmuch as it brings about new forms of social interaction, relationship, knowledge, and capacity, and this productivity consists in the ways that the exercise of institutional power generates challenge and resistance.

Foucault's conceptualization of power is particularly germane to understanding the struggle over issues such as corporate responsibility and accountability because it captures the dynamic, contentious and agonistic nature of power relations. This fluidity distinguishes relations of power from relations of domination, which are solidified, immobile and immune to resistance (Foucault 1988a). While relations of domination do not disappear in modern society, relations of power become increasingly prevalent inasmuch as social and political forces and capacities are focused on enhancing, shaping, and directing life and the social conditions of life, rather than on limitation and deprivation. Both power relations and relations of domination entail subjugation, but the two vary considerably in the ways that they function. Domination is unilateral, coercive and total; it functions through imposition; and its logic is repressive. Power, on the other hand, is the product and medium of social contingency (and the expansion of contingency is a defining feature of modernization). Power only functions in situations where those on whom it is exercised have the possibility of reacting otherwise. Contingency presupposes the possibility of different courses of action, and can therefore only be directed at those who exercise a measure of freedom over their actions. Those who exercise power may seek to totalize its effects, but these effects are never exhaustive as the contingency of power relations allows for resistance and even reversal. Power relations are multilateral and open-ended 
inasmuch as contingency multiplies the techniques and instruments of power and changes its operational logic from imposition to intervention. Power functions primarily not through constraining and preventing, though it may result in these effects, but through producing new patterns of social practice together with discourses of knowledge and truth that legitimate and objectify these practices in an effective way.

Unlike domination, which acts in ways that are specific to particular situations or events, power functions continuously because the objective of producing and shaping conduct means that the exercise of power is more than a self-referential undertaking. The function of domination is to reproduce domination; the function of power is to produce something new, to induce, encourage, incite, and direct. Power is not a commodity that can be possessed and accumulated; it is a kind of energy that only exists in its exercise and ramifications (1980b). The exercise of power, moreover, is targeted not at people, but at their actions or conduct. Foucault (1988a) defines power in terms of the reflexivity of action, as an action upon action, whether someone else's or one's own. This means that the exercise of power seeks to internalize its effects in the subjectivity of those to whom it is directed, and become self-activating. Power, for Foucault, is about how we are made subjects in the dual sense: on the one hand, actors capable of selfreflection and rational conduct, of knowing and being known; on the other hand, actors marked by subjugation, bound to themselves and others in relations that are asymmetric or hierarchical (1980a).

There are three aspects of Foucault's analysis of the power/struggle nexus that are valuable for understanding contention around the GC and the struggle for corporate accountability. Firstly, power relations are bound up with the process of social problematization (Foucault, 2000). The exercise of power presupposes that some condition, event, or mode of 
action is problematic in some way, and is capable of resolution or improvement. It is through problematization that the exercise of power is tied to the mobilization of ethical values and the production and circulation of knowledge in which the problematic is framed and explained. Secondly, Foucault (2003) argues that power does not function without resistance, struggle, and confrontation. The exercise of power is always (potentially) contentious. Power is leaky; the problems it addresses and seeks to subsume can escape its embrace to some extent, not the least because the exercise of power itself can be reflexively and contingently problematized. The organization and focus of resistance and struggle, thirdly, are determined by the particular ways that power is exercised. Power does not have a single, unitary identity or modality. It is finely differentiated in terms of the techniques through which it is exercised, the problems it addresses, and the ways that it can be resisted and attacked. Given the contingent nature of power, these techniques may complement one another or they may clash. Resistance and struggle are possible inasmuch as any technique of power can be challenged by deploying the same or some other technique of power as the basis for counter-claims, counter-demands, and counter-action.

\section{Problematizing of the Global Compact}

Contention and controversy over the GC and corporate accountability have varied focal points and entail an array of different actors and interests. The field of contention is based largely on the triangular relationship between TNCs, the UN, and NGOs and other social movement organizations mobilized around social justice and environmental sustainability. Each of these comprises a network of individual actors whose own interests and stakes may vary and even conflict. Some international NGOs such as Oxfam and Amnesty International are participants in the GC, whereas others, such as Greenpeace, are not. The same is true for large TNCs and labour 
movement organizations. More TNCs have been joining the GC, but it still seems to be viewed sceptically by US-based transnationals whose size and scope make them crucial to its long-term feasibility. Because of this triangularity, the lines of engagement are more complex than in bilateral forms of struggle. The GC is trying to influence and cajole TNCs into taking action to respect and support its ten principles, and to encourage NGOs to join and engage in partnerships with TNCs to facilitate 'best practices' learning. At the same time, activists are trying to put pressure on both the GC and TNCs to strengthen implementation, enforcement, and accountability measures with respect to human rights and environmental protection. TNCs, on the other hand, are generally attempting to resist stronger measures that they see as a tool to curtail their field of autonomy and advantage, while in many cases recognizing the need to espouse the discourse of social responsibility.

For its advocates, CSR initiatives are a solution rather than a problem. The problem lies in the social and environmental side effects of the expansion of market relations that threaten the latter's long term viability. Neo-liberalism enhances the autonomy of the market, but the obverse is the increasingly transparent indifference, if not hostility, of the market to societal and environmental issues and values that cannot be calculated in terms of short-term cost and benefit. The property rights on which markets are based are exclusionary and resistant to democratic values that are not mediated through monetary exchange, and have given TNCs too narrow a view of their own identity and potential. From the viewpoint of CSR advocates, then, the fundamental problem is one of lack: corporations lack sufficient awareness of the problems that market globalization fosters as well as sufficient understanding of the role that they can and should play as 'citizens' in circumstances where governments do not have the will and/or capacity to act effectively to meet social and environmental needs. By casting this role in the 
language of responsibility rather than obligation, CSR advocates soften both the attribution of causal blame for social and environmental problems and the strength of any normative requirement on TNCs to assume the costs and risks of remedial action.

There is nothing especially new in this discourse of the beneficent, ethically rational capitalist apart from a heightening of the stakes, particularly with respect to the environment. The theory of social economy arose in the early $19^{\text {th }}$ century in response to the social problems resulting from the rapid growth of capitalism in Western Europe. What was deemed problematic was not the effect of market relations on the unequal distribution of wealth and power, but the impact of these inequalities on social relations and personal conduct. The problem was not poverty, which was seen as an incentive to industriousness and diligence, but pauperism, the tendency for many of the poor to be undisciplined, licentious, dissolute, unreliable, prone to criminality, and so on (Procacci 1991). The remedy lay in persuading capitalists to recognize their longer term, 'enlightened' self-interest in addressing these social problems through educational intervention to ensure that paupers became the respectable poor. Philanthropy, as opposed to charity, entailed initiatives to reform the conduct of those who lost out in the competition for market success rather than simply providing supplementary compensation.

The morally self-righteous language has since largely disappeared, but the essential narrative remains untouched: like philanthropy before it, CSR is a supplement and complement to market relations. What has changed, however, is the scale of the problems. Globalization has closed off the opportunity for the problematic side-effects of market relations to be externalized; there are no more empty spaces in which to relocate the system's unwanted by-products, be they surplus populations or toxic emissions (Beck 1992). Appeal to the enlightened self-interest of global capital can no longer be confined to the local level. The globalization of problematic side- 
effects has given rise to a new discourse oriented around sustainability, or rather the unsustainabilty of business-as-usual practices concerned only the maximization of short-term profit and shareholder value. Sustainability has obvious environmental connotations, and it signifies the way that the rhetoric of environmental responsibility has become a common aspect of the legitimation and reputation strategies of TNCs. Sustainability is also broad enough to subsume social as well as environmental problems but without the need to reform radically the imperatives, objectives or structures of the market system. Sustainability means simply finding less problematic ways to ensure system continuity and stability under conditions where externalizing social and environmental costs is less of an option. This turns CSR into a kind of prospective and pre-emptive form of crisis management.

In the case of the GC the problem is framed primarily in terms of rights and the responsibility of TNCs to respect and support these rights. The assumption behind the Compact is that respecting and supporting human, labour and environmental rights will help ensure longterm viability of the global market system, enhance corporate legitimacy and enable TNCs to see the rational benefits of ethical practices. The GC rightly assumes that human, environmental, and labour rights are constantly under threat of violation and abuse. The notion of respecting and supporting rights, however, frames the relationship between TNCs and rights abuses in an indirect way, as complicity or ignorance rather than intent or indifference. In practice, therefore, respecting and supporting rights translate chiefly into better avoidance behaviour: avoiding situations in which one might benefit from abuses carried out by others (such as host governments). Even in the case of labour rights, where TNCs are most likely to be in a position to commit violations, the problem is still defined in terms of avoidance: avoiding the use of forced labour, interference in workers' attempts to unionize, and discrimination in hiring and 
firing. To respect, even to support workers' right to freedom of association does not per se mean taking active steps to ensure that employees are unionized. Rights are notional. They entail the freedom to make claims or demands without fear of harm or disadvantage, but the realization of these demands is not necessarily guaranteed simply by the act of claims making.

For critics of CSR and the GC the problem is a mixture of excess and lack: excessive power and autonomy on the part of TNCs and lack of a framework to ensure and enforce TNC accountability on the part of the GC. Criticism of the GC is part of a larger opposition on the part of the global social justice movement to neo-liberalism and the growing autonomy of the market sphere at the expense mechanisms of social control and democratic accountability. While social movement activists also tend to frame the problem through the lens of rights, their argument is that voluntary, self-policing systems of CSR like the GC are seriously inadequate as they amount simply to a public relations exercise by TNCs whose public image is a primary ingredient of their marketing and consumer relations strategies. CSR simply continues earlier practices of corporate philanthropy by softening symbolically the hard edges of market-generated inequalities and inequities, and generating additional forms of social dependency on the interests of organized capital. For activists, then, the problem with CSR is threefold: it is far too weak a mechanism for controlling corporate power and conduct; it reinforces relations of social dependence that are not subject to democratic decision-making; and it functions as a way to enhance the commercialization and corporate control of the public sphere where debate over social issues is distorted by the power of public relations.

\section{Struggle and Strategy}

Foucault insisted that wherever power relations function so too do relations of resistance, 
and it is resistance that gives power relations their contingent character. Foucault (1983) identifies three different types of resistance or struggle: against domination, exploitation, and subjection or 'subjectivization.' Struggles against domination are directed at loosening the grip of sovereign or state control, and are usually organized in terms of the extension and 'reflexivization' of legal rights (the right to rights). Struggles against exploitation are characteristic of the working class movement directed against economic power that separates people from the produce of their labour. Struggles against subjection are aimed at the exercise of power that ascribes differential social identities and ties people to these identities in individualizing ways. Although Foucault recognises that any struggle can involve dimensions of all three types, he argues that one type of struggle tends to be predominant in any concrete situation. These struggles form a broad historical sequence, beginning in early modernity with struggles against domination (against the absolutist state), followed by struggles against exploitation in the period of industrialization, and culminating in "struggles against subjection, against forms of subjectivity and submission" in late modernity (Foucault 1983, 212).

Foucault's claim that struggles against subjection/subjectivization are becoming more important in late modernity echoes the argument that the focus of political contention is now concerned increasingly with 'post-materialist' values and the politics of identity or recognition that characterize the 'new' social movements (Bennett 1998). For Foucault, these struggles against subjectivization are "transversal" (occurring across societies), aimed at immediate power effects rather than underlying institutional structures, and concerned with both the status of the individual and the exercise of power based on "the privileges of knowledge" rather than other resources such as wealth or coercion $(1983,211-212)$. While this characterization fits many of the struggles associated with identity or recognition politics in late modern societies, it does not 
fully represent a hybrid movement such as the global social justice movement. Activist challenges to the GC and CSR also resemble struggles against domination inasmuch as they support the extension and substantiation of rights in the face of repressive or undemocratic governments, and against exploitation to the extent that they seek to strengthen the power of workers via freedom of association and to eliminate forced and child labour.

Where the movement challenging the GC and CSR does resemble struggles against subjection are in the areas of strategy and modes of activism. To the extent that struggles against subjection problematize identity and identity relations, they have a strong ethical and cultural component. Identity is first and foremost about the meaning and evaluation of the self (individual and collective), which lends itself to strategies of contention and repertoires of tactics that have a strong communicational orientation. In his analysis of power and strategy, Foucault (1983) argues that the exercise of power forms part of systemic "blocks" that also include relations of communication as well as relations of material resources and capacities. These sets of relations, while analytically discrete, are empirically superimposed and interactive; each is implicated in the realisation of the others-using "each other mutually as means to an end"-but in an uneven, contingent way (Foucault, 1983, 218). In the case of struggles against subjectivization, whose initial objective is to change understandings, the exercise of power accentuates relations of communication and the use of communicative action.

While the movement challenging the GC and CSR has objectives that entail much more than changing understandings, this remains the initial-and recurrent-problem that mobilization must address. This problem is shared by all universalistic or altruistic movements to the extent that their main constituents are not the primary intended beneficiaries of activism (Gamson 1975; Melucci 1996). The problem is intensified, however, by the transnational nature of the central 
issues being addressed, viz. how to make TNCs more accountable for their human, labour, and environmental impact, particularly in the global South, and how to induce the GC to accept that stronger measures than a voluntary system of good intentions and self-reporting are needed. The movement is often dealing with problems that do not have an immediate, direct, or concrete impact in the global North. Threats to or the actual abuse of rights do not usually manifest themselves in the form of events that can easily be understood in terms of risk, crisis, or some other form of grievance conducive to large-scale mobilization. Framing, in other words, is problematic and this accentuates the communicational stakes in the development and deployment of movement strategy.

The transnational, network form of movement organization also enhances the communicational dimension of activism. The movement for social justice has to mobilize and coalesce a disparate and dispersed constituency of members and supporters whose activism is itself often primarily communicational-petitions, letters, placards, leaflets, posters, public protests, symbolic culture jamming. The challenges of constituency mobilization and coordination are compounded by the need to establish lines of interaction with intended beneficiaries whose own social and cultural life contexts, experiences, and opportunities often differ significantly. Communication becomes critical as a means to manage these relationships, but also as a potential point of friction and additional problems whose solution lies partly in better communication. Communication becomes an integral and reflexive aspect of movement strategy that is key to ensuring the capacity to respond in a timely, flexible, and effective way to the actions of those who are better equipped with material and technical resources.

Because social movements typically lack access to significant material resources and capacities, communication-centred strategies are often directed at the exposure and ethical 
denunciation of both the actions and credibility of institutional opponents. Activism depends for its own credibility on opening up the breach between what institutions say-their claims to ethical responsibility and responsiveness-and how they actually behave. Activists attempt to use CSR as leverage to demonstrate how actions fall short of, if not contradict, claims. In any field of contention, strategy comprises not only objectives and the means to achieve these, but also the process of attempting to deprive opponents of opportunities, meanings and other resources-their "means of combat" -to gain advantage (Foucault 1983, 225). By demonstrating not only how powerful institutions act in ways that are potentially harmful, especially to the socially vulnerable, but also how they are hypocritical and untrustworthy in failing to practise what they preach, social justice activists are able to mobilize additional normative resources that help to offset the disadvantages they face. By revealing the hypocrisy of their opponents, activists seek to deprive them of legitimacy by undermining trust, instilling doubt, and introducing risk into institutional environments.

The centrality of claims and counter-claims making to communicational politics carries with it the 'post-modern' dilemma: how does the public decide the validity and merit of different, contesting views. Activists have been able to exploit this dilemma by exposing not only the breach between the words and actions of their opponents, but also the contradictions within their opponents' claims and practices. Critics of the GC, for example, have been able to use the UN against itself. In its criticisms of the GC ACFUN has used the existence of a stronger model to secure corporate accountability that has been developed elsewhere in the UN system, viz. the U.N. Norms on the Responsibilities of Transnational Corporations and Other Business Enterprises with Regard to Human Rights, also known as the U.N. Norms for Business (United Nations Commission on Human Rights 2003). The Norms call for more stringent control over 
and accountability by TNCs than the GC's code of principles. Using an opponent's own norms and institutional processes as a basis for challenge helps to undermine credibility, reliability, and trust, and there are signs that this tactic has had some effect. While the GC still lacks any effective monitoring or binding decision-making capacity over its corporate affiliates, it has moved to strengthen what it calls "integrity measures" by introducing a third-party complaint mechanism and, in 2006, suspending the membership of 335 companies. What is striking, however, is that these companies were "delisted" not for failing to make progress in implementing the Compact's principles, but for failing to communicate what progress if any they had made (Ethical Corporation 2007).

\section{Power and Counter-Power}

Foucault argued that power is a force or energy that can only be identified in the manner of its exercise. Foucault's analyses of power were always concerned with the how of power rather than the why, and were focussed on the diverse techniques for exercising power (Foucault, 1988b). Foucault identified four different "technologies" or modes of power-sovereignty, disciplinary power, regulation or "biopower," and pastoral power (inter alia Foucault, 1977, 1983 , 1988c, 2003). He saw each mode developing in something of a historical progression that begins with sovereignty in the pre-modern period, and extends into the modern period with the expansion of legal rights (the "democratization" of sovereignty), discipline, regulation, and secular forms of pastoral power closely tied to the growth and centralization of the state and its administrative apparatus. Each technology of power develops as social and demographic changes generate new problems that escape the purview of existing forms of power. For Foucault, the historical development of these different forms of power is cumulative as each new mode 
problematizes and sharpens the functioning of existing modes rather than supplanting them.

These different technologies of power become superimposed on one another and form a matrix of interacting techniques.

Each mode consists of particular techniques through which power is enacted, and operates at a particular level. Sovereignty functions largely through legal rights and the requirement that those subject to sovereign power respect and obey the law. Sovereignty is a totalizing mode of power inasmuch as legality, right and obligation apply to social aggregates such as populations. Discipline functions through techniques such as regimented drilling, training, surveillance, and testing aimed at making bodies more productive, efficient and pliable or docile at the level of local institutions such as workplaces and schools. Discipline operates on an individualizing level. It is aimed at social normalization by making individual actions visible and legible to authority, and by encouraging self-discipline through the internalization of selfmonitoring. Regulatory power also has normalizing or regularizing functions but these are oriented to the promotion of security and the management of threats or risks to life at the level of populations. Regulation is realized through the application of science to measure, forecast and generate knowledge about threats, and the implementation of standards and practices to assure the conditions that sustain life in areas such as health, hygiene, and public safety. Pastoral techniques, which are religious in origin and are revived and secularized in the modern period, consist in the exercise of power through care-giving oriented to individual welfare, selfknowledge, responsibility, and solidarity at the level of local communities.

Sovereignty (legal rights), discipline, regulation and pastoral techniques extend and intensify the effects of power throughout all levels of social and personal life, and establish different rationalities for the exercise of power (order and justice, security and risk management, 
well-being and solidarity). Power relations infuse the "capillary" level of social life as the exercise and effects of power spread everywhere in the form of legal rights, socialization, regulation, normative and technical standards, surveillance, risk management practices, measurement procedures, testing, care-giving, confessional practices, and so on. The obverse of this growth in the differentiation and reach of power effects is a gradual narrowing and reduction in the capacity of the social system to externalize problems as a way of resolving them. The growth and differentiation of power techniques is a response to this narrowing but also a factor that contributes to it by investing social spaces and processes with the rationalities of power. In this way, the permeation of power simultaneously intensifies the problematization of life as the exercise of power rebounds back on itself as an additional source of contentiousness: rights can conflict with rights, discipline can alienate, regulation can become rigid, and pastoral techniques can create dependency. As Foucault insisted, all forms of power are "dangerous" $(2005,266)$.

Power not only invests social relations with legal, disciplinary, regulatory, and pastoral force, it also makes these relations contestable as points of challenge where the exercise of power is resisted, evaded, even reversed. What this speaks to, however, is not a dichotomy of power and resistance, but to resistance as the exercise of counter-power. As Foucault (1980b) noted, the exercise of power by one means is resisted by the deployment of power by other means. Resistance does not function outside the logic of power; it is a reaction to an action upon actions. We invoke rights to limit the effect of discipline or regulation; we call for regulation and caregiving to offset the realization of rights for some at the expense of others; and those who challenge the exercise of power often succeed best when they impose some measure of discipline on themselves. Resistance compounds the logic of power while nullifying or qualifying its effects with the counter-effects of other kinds of power. 
The historical evolution of these different modes of power means that their relationship to one another is uneven. Contention over the GC and CSR demonstrates how legal right remains the primary point of reference for the exercise of power in ways that are not only legitimately binding but also accountable. Legal rights dovetail with regulatory modes of power inasmuch as both are totalizing in scope, and therefore lend themselves to the exercise of and challenge to power at the aggregate level of social relations. The struggle over the GC is in this sense straightforward in its objectives, viz. to replace a voluntary system of self-monitoring, -reporting, and -correction with a more binding, enforceable system of sanctionable regulation and accountability. The problem is that this goal cannot be implemented from within civil society alone, without governmental power. This problem is compounded by globalization inasmuch as TNCs are often most likely to be complicitous in rights abuses or environmental harm in developing countries where governments lack the will and/or capacity to implement and enforce protection of rights. Moreover, enormous disparities in material resources, as well as the neoliberal privileging of property rights and market discipline over social welfare, have meant that TNCs enjoy far greater access to governments than do civil society groups.

Although civil society lacks the legally binding capacity to sanction corporate and governmental actors, it can nevertheless use the public sphere to pressure and influence these actors. Invoking and promoting the U.N. Norms for Business is not only a tactical device to gain leverage by using the U.N. against itself, it is also a more effective strategic tool to regulate corporate conduct, and to ensure compliance with and support and promotion of human and environmental rights. The U.N. Norms for Business constitute a more stringent regulatory code that could eventually impose definite obligations and responsibilities on corporations in a way that identifies the boundaries between property rights and human rights. Unlike the GC's ten 
principles, which are defined in very general terms, the U.N. Norms for Business spell out in some detail the measures that TNCs should take to respect and implement labour rights (including the protection of children from economic exploitation), human rights, national sovereignty, consumer protection, and environmental protection.

The most significant difference between the U.N. Norms for Business and the GC is the fact that the Norms emerged from the U.N. Commission on Human Rights, while the GC represents a wholly new institutional creation. Because of their institutional location as part of the existing international human rights machinery, the U.N. Norms for Business will require greater scrutiny of TNC activity as it relates to human rights. The discussions around the Norms have noted that the discrepancies of power between states and corporate actors require efforts to hold non-state actors accountable to international human rights laws, even though governments are technically the responsible parties to international treaties. The creation of a new institutional arrangement through the GC should then be seen as a conscious attempt to skirt established U.N. practices for human rights monitoring and reporting.

In 2005, the U.N. Commission on Human Rights authorized the creation of a Special Representative on the issue of Human Rights, Transnational Corporations and other Business Enterprises whose mandate includes the development of standards of corporate accountability and methodologies for assessing the impact of business activities on human rights. Amnesty International, a major NGO participant in the GC, has actively worked to promote the Norms in the U.N. Commission on Human Rights and to educate the public and human rights practitioners about them. Amnesty International's website devotes hardly any attention at all to the GC while providing extensive background on the history and current status of the Norms. These two competing schemes for global CSR offer substantially different possibilities for regulating the 
practices of TNCs. Because the Norms threaten to bring new scrutiny to corporate practices regarding human rights, they have faced strong resistance from TNCs, and one might also argue that they encourage more businesses to participate in the GC as way of heading off any effective international monitoring and sanctioning of corporate actions.

The elaboration of rights and the implementation of regulatory codes are necessary but not sufficient conditions to achieve corporate, and governmental, responsibility and accountability. Rights and regulation presuppose universality (rights) and standardization (regulation), which gives them breadth of coverage and enables them to be exercised at a distance through the institutional mediation of criminal, civil, and administrative law. But as modes of power they are also leaky, and would remain so even if global institutional complexity did not expand the possibilities for evading legal and regulatory norms, and governments were committed to enforcing these norms. When legal requirements or regulatory standards are seen as restrictive, meeting them becomes a matter of the minimal level of performance necessary to avoid violation or non-compliance. Norms and standards easily become formalized, and this encourages a literalist interpretation that circumvents and threatens to undermine the concrete benefits that they are intended to achieve. This is particularly so under competitive conditions in which national government capacity and desire to implement transnational legal and regulatory structures have been weakened by neo-liberal hegemony. One way to offset the restrictive implications of legal and regulatory structures may be to tie them to incentive structures. For example, the US-Cambodia textile agreement offers a model for incorporating the effective regulation of labour standards into international trade agreements between developing and developed countries (Wells, 2006). The agreement illustrates the feasibility of expanding regulatory oversight of human, consumer, and environmental as well as labour rights in 
developing countries via trade and development arrangements that secure market access and other forms of advantageous treatment in return for compliance with rights and standards.

One of the principal insights of Foucault's conceptualization of power is that different techniques of power work on different social levels and are organized in terms of different rationalities of value. Because modes of power are not only leaky but also dangerous, different techniques of power have to be used not only to complement but also to offset one another. Any attempt to make TNCs, governments and other central institutions more responsible and accountable by submitting them to effective democratic governance has to deploy techniques of power on both the macro and micro levels: rights and regulation have to be supplemented by disciplinary and pastoral techniques such as surveillance, monitoring, instruction, and provision of the means of material, social, intellectual, and emotional well-being at the local level. What facilitates this is the way that modes of power at the macro and micro levels are complementary in terms of their value rationalities. Though they function on different levels, discipline and regulation are oriented to order, security, and efficiency, while rights and pastoral techniques pertain principally to welfare, equity, and social cohesion. For each couplet, the mode of power at the local level is the means of substantiation of the mode of power at the macro level.

At the micro level, power functions through proximity rather than at a distance, and this reduces the possibility of mediating the ways that power is exercised. For civil society actors such as NGOs proximity is risky, not least because it carries the possibility of compromise or dependency. It is precisely this kind of risk that the GC itself poses inasmuch as it may function as a forum to regulate and discipline its civil society participants by incorporating them within an institutional framework of standardized procedures and practices. When power is exercised through proximity, autonomy is at stake. To preserve and enhance autonomy, activists and other 
civil society actors that lack material resources and are faced with restricted opportunity structures have to reduce risk by means of risk: they have to replace distance with uncertainty. Civil society actors have to deploy communication in ways that use the public sphere as an instrument of risk inducement in corporate and governmental environments. It is by making these environments uncertain and unpredictable that civil society actors can enhance their own autonomy and exert more effective pressure on institutional power centres in the direction of democratic responsibility and accountability. To accomplish this means engaging with corporations and governments on terms that are contingent and conditional rather than institutionally standardized.

\section{Conclusion}

Our analysis has sought to apply Foucault's conceptualization of power to the efforts by the international community to respond to corporate violations of human rights and other global norms. While this problem is defined in terms of rights and the balance of rights, it is also an issue of the different ways in which power is exercised on both the macro and micro levels of social organization, as well as different rationalities of value that the exercise of power addresses. We have shown how the attempts to expand global CSR regimes through the UN Global Compact and the UN Norms for Business have been limited in their ability to impact actual practices, and this is largely due to the fact that these arrangements fail to address fundamental imbalances of autonomy as well as disciplinary and regulatory powers between TNCs and states. Moreover, neoliberalism has undermined the pastoral or care-giving capacities of states, further eroding their ability to respond to the challenges of economic globalization. Attempts to promote CSR as a remedy to corporate violations of social norms are problematic in that they have only minimal effects on autonomy as well as disciplinary and regulatory power. 
What becomes clear is that any attempt to curb effectively socially harmful corporate practices will require efforts to restructure fundamentally power relations between states, international institutions, and TNC. Instead of serving as partners to global CSR schemes, civil society actors would be more effective if they work to reclaim the state-by which we mean re-asserting its autonomy from markets as well as its disciplinary, regulatory and provisionary power over them.

\section{References}

Amnesty International. 2004. "Global Compact Leaders Summit: NGO Participants Raise Concerns." Accessed at <http://web.amnesty.org/web/web.nsf/print/ec-letter-240604-eng>

Amnesty International. 2005. Contracting Out Human Rights: The Chad-Cameroon Pipeline Project. Accessed at <http://web.amnesty.org/library/pdf/POL340122005ENGLISH/\$File/POL34012o5.pdf>

Beck, Ulrich. 1992. The Risk Society: Towards a New Modernity. Translated by Mark Ritter. London: SAGE Publications.

Bendell, Jem. 2004. "Flags of Inconvenience? The Global Compact and the Future of the United Nations." ICCSR Research Paper Series No. 22-2004, Nottingham University, ISSN 1479-5124. Accessed at <http://www.globalpolicy.org/reform/business/2004/flags.pdf〉

Bennett, W. Lance. 1998. "The Uncivic Culture: Communication, Identity, and the Rise of Lifestyle Politics." PS: Political Science and Politics 31, no. 4: 41-61.

Bennett, W. Lance. 2003. "Communicating global activism: strengths and vulnerabilities of networked politics." Information, Communication and Society 6, no. 2: 143-168.

Blowfield, M. 2005. "Corporate Social Responsibility: Reinventing the Meaning of Development?" International Affairs 81, no. 3: 515-524.

Blowfield, Michael and Jedrzej George Frynas. 2005. "Setting New Agendas: Critical Perspectives on Corporate Social Responsibility in the Developing World." International Affairs 81, no. 3: 499-513.

CorpWatch. 2002. "Greenwash + 10: The U.N.'s Global Compact, Corporate Accountability and the Johannesburg Earth Summit." Accessed at $\langle$ http://www.corwatch.org/downloads/gw10.pdf > 
della Porta, Donatella, Massimiliano Anretta and Herbert Reiter. 2006. Globalization From Below: Transnational Activists and Protest Networks. Minneapolis and London: University of Minnesota Press.

Ethical Corporation. 2007. "The UN Global Compact - Surviving Without Annan." Accessed at <http://www.ethicalcorp.com/content.asp?ContentID=4928>

Foucault, Michel. 1977. Discipline and Punish: The Birth of the Prison. Translated by A. Sheridan. New York: Pantheon Books.

Foucault, Michel. 1980a. "Truth and Power." Pp. 109-133 in Power/Knowledge: Selected Interviews and Other Writings 1972-1977, ed. Gordon, Colin. Translated by Gordon, Colin et al. New York: Pantheon Books.

Foucault, Michel. 1980b. “Two Lectures.” Pp. 109-133 in Power/Knowledge: Selected Interviews and Other Writings 1972-1977, ed. Gordon, Colin. Translated by Gordon, Colin et al. New York: Pantheon Books.

Foucault, Michel. 1983. "The subject and power.” Pp. 208-226 in Michel Foucault: Beyond Structuralism and Hermeneutics, ed. Dreyfus, Herbert and Paul Rabinow. $2^{\text {nd }}$ edition. Chicago: University of Chicago Press.

Foucault, Michel. 1988a. "The ethic of care for the self as a practice of freedom: an interview." Pp. 1-20 in The Final Foucault, ed. Bernauer, James and David Rasmussen. Translated by Gauthier, J. D. London and Cambridge, Mass.: The MIT Press.

Foucault, Michel. 1988b. “On Power.” Pp. 96-109 in Michel Foucault. Politics, Philosophy, Culture: Interviews and Other Writings 1977-1984, ed. Kritzman, Lawrence. Translated by Sheridan, Alan. New York and London: Routledge.

Foucault, Michel. 1988c. "Politics and Reason." Pp. 57-85 in Michel Foucault. Politics, Philosophy, Culture: Interviews and Other Writings 1977-1984, ed. Kritzman, Lawrence. Translated by Sheridan, Alan. New York and London: Routledge.

Foucault, Michel. 2000. "Governmentality." Pp. 201-222 in Power: Vol. 3 of the Essential Works of Foucault 1954-1984, ed. Faubion, James. Translated by Hurley, Robert et al. In New York: The New Press.

Foucault, Michel. 2003. "Society Must Be Defended”: Lectures at the Collège de France 19751976. Translated by Macey, David. New York: Picador.

Foucault, Michel. 2005. "Is It Useless to Revolt?” Pp.263-267 in Foucault and the Iranian Revolution: Gender and the Seductions of Islam, ed. Afaray, Janet and Kevin B. Anderson. Chicago and London: The University of Chicago Press. Originally published in Le Monde, May 11-12, 1979: 1. 
Frynas, Jedrzej George. (2005) "The False Developmental Promise of Corporate Social Responsibility: Evidence from Multinational Companies.” International Affairs 81, no. 3: 581-598.

Gamson, William. 1975. The Strategy of Social Protest. Homewood, Ill.: The Dorsey Press.

Greenleaf Publishing. 2004. "The U.N. Global Compact: A Primer on the Principles." Accessed at 〈http://www.greenleaf-publishing.com/pdfs/rtbprime.pdf>

Hughes, Steve and Rorden Wilkinson. 2001. "The Global Compact: Promoting Corporate Responsibility?” Environmental Politics 10, no. 1: 155-159.

Jenkins, Rhys. 2005. "Globalization, Corporate Responsibility and Poverty." International Affairs 81, no. 3: 525-540.

Joint Civil Society Statement on the Global Compact and Corporate Accountability. 2004. Accessed at <http://www.globalpolicy.org/reform/business/2004/07gcstatement.pdf>

Martens, Jens. 2004. "Precarious 'Partnerships': Six Problems of the Global Compact Between business and the U.N.." Global Policy Forum. Accessed at <http://www.globalpolicy.org/reform/business/2004/0623partnerships.htm>

Melucci, Alberto. 1996. Challenging Codes: Collective Action in the Information Age. Cambridge: Cambridge University Press.

Newell, Peter. 2005. "Cittizenship, Accountability and Community: the Limits of the CSR Agenda." International Affairs, 81 (3): 541-557.

Paine, Ellen. 2000. "The Road to the Global Compact: Corporate Power and the Battle over Global Public Policy at the United Nations." Global Policy Forum. Accessed at <http://www.globalpolicy.org/reform/papers/2000/road.htm>

Procacci, Giovanna. 1991. "Social economy and the government of poverty." Pp. 151-166 in The Foucault Effect: Studies in Governmentality, ed. Burchell, Graham, Colin Gordon and Peter Miller. Chicago: University of Chicago Press.

Ruggie, John Gerard. 2004. "Reconstituting the Global Public Domain - Issues, Actors, and Practices." European Journal of International Relations 10, no. 4: 499-531.

Shamir, Ronen. 2004. "The De-Radicalization of Corporate Social Responsibility." Critical Sociology 30, no. 3: 669-689.

Simons, Penelope. 2004. "Corporate Voluntarism and Human Rights: The Adequacy and Effectiveness of Voluntary Self-Regulation Regimes." Relations industrielles/Industrial Relations 59, no. 1: 101-42. 
Smith, Jackie, John McCarthy, Clark McPhail and Boguslaw Augustyn. 2001. "From Protest to Agenda Building: Description Bias in Media Coverage of Protest Events in Washington." Social Forces 79, no. 4: 1397-1423.

Transnational Resource and Action Center. 2000. "Tangled Up in Blue: Corporate Partnerships at the United Nations." Accessed at <http://www.corpwatch.org/downloads/tangled.pdf>

United Nations Commission on Human Rights. 2003. "Economic, Social, and Cultural Rights: Norms on the responsibilities of transnational corporations and other business enterprises with regard to human rights." Accessed at <http://www.unhcr.ch/huridoca.nsf/(Symbol)/E.CN.4.Sub.2.2003.12.Rev.2.En?Opendoc ument>

United Nations Environmental Programme. 2002. Guide to the Global Compact: A Practical Understanding of the Vision and Nine Principles. Accessed at <http://uneptie.org/outreach/compact/docs/gcguide.pdf>

United Nations Global Compact. 2006. "The Ten Principles.” Accessed at <http://www.unglobalcompact.org/AboutTheGC/TheTenPrinciples/index.html>

Utting, Peter. 2002. "The Global Compact and Civil Society: Averting a Collision Course." Development in Practice 12, no. 5: 644-647.

Wells, Donald. 2006. "'Best Practice' in the Regulation of International Labor Standards: Lessons of the US-Cambodia Textile Agreement." Comparative Labor Law and Policy Journal 27, no. 3: 357-376.

Williams, Oliver. 2004. "The U.N. Global Compact: The Challenge and the Promise." Business Ethics Quarterly 14, no. 4: 755-774. 